\title{
The Myth of the Additive Effect of The Transformational Leadership Model
}

\author{
Massad Awdah Alatawi \\ Taibah University \\ E-Mail: matawi@taibahu.edu.sa
}

\begin{abstract}
This paper reexamines the additive effect of the transformational leadership model to refine the perception of the transformational leadership theory. It concludes that transformational leadership does not produce a total effect the same as the sum of the effects of the four I's. It argues that the additive effect of transformational leadership is a myth and that the four I's do not have an additive influence. Therefore, researchers should not introduce the four I's as a legitimate model of transformational leadership. For future research, this paper highlights the need for a new theory that justifies transformational, transactional, and laissez-faire leadership styles with conceptual clarity.
\end{abstract}

Keywords: Additive Effect, Transformational Leadership, Four I’s, Myth, Conceptual Clarity

\section{INTRODUCTION}

Bass and Avolio formulated the additive effect of transformational leadership model in 1990 as a theoretical explanation of transformational leadership. An additive effect implies an effect in which two or more variables, used in combination in a model, produce a total effect that is the same as the sum of the individual effects (Weathington, Cunningham, \& Pittenger, 2010). Some researchers who have analyzed this model have claimed an additive effect gained from four components of transformational leadership that contribute to results that are superior to the results of other leadership styles, such as transactional and laissez-faire. The ideological concept of the current model initiates that transformational leadership produces superior effects compared to transactional leadership. While transformational leadership yields performance beyond expectations, transactional leadership yields expected outcomes (Avolio, 2011; Bass \& Avolio, 1990; Bass \& Riggio, 2006; Erkutlu, 2008; Gellis, 2001; Grant, 2012; Hall, Johnson, Wysocki, \& Kepner, 2015; Hamstra, Van Yperen, Wisse, 
\& Sassenberg, 2014; Northouse, 2013; van Knippenberg \& Sitkin, 2013).

Lussier and Achua (2012) defined transformational leadership as a process whereby a manager serves to change the status quo by identifying problems in the current system and providing a new vision of what the organization could be. Transformational leadership comprises four factors known as the four I's: idealized influence (II), inspirational motivation (IM), intellectual stimulation (IS), and individualized consideration (IC). These four I's make up the additive variables of the reviewed model. II results from directors who are trustworthy and respectful and who set themselves as role models. IM results from administrators who promote trust, involvement, and cooperation among team members. IS results from supervisors who foster innovation and critical thinking to challenge assumptions. IC results from leaders who act as coaches and give recognition to staff (Avolio, 2011; Bass \& Riggio, 2006; Caillier, 2014; Dabke, 2016; Grant, 2012; Hall et al., 2015; Zhu \& Akhtar, 2014). Proponents of II, IM, IS, and IC have claimed that these four I's are independent, are distinct, coexist, and have an additive effect (Avolio, 2011; Bass \& Avolio, 1990; Erkutlu, 2008; Gellis, 2001; Hall et al., 2015).

Some studies have challenged the conceptual clarity of the transformational leadership model, especially the construct validity of the four I's (Alatawi, 2013, 2015; Lee, 2014; MacKenzie, Podsakoff, \& Jarvis, 2005; Northouse, 2013; Rickards \& Clark, 2006; Tejeda, Scandura, \& Pillai, 2001; Tracey \& Hinkin, 1998; van Knippenberg \& Sitkin, 2013). Research has confirmed that the four I's overlap with each other, thus implying that they are not distinctly delimited (Lee, 2014; MacKenzie et al., 2005; Northouse, 2013; Rickards \& Clark, 2006; Tracey \& Hinkin, 1998). Lee (2014), Northouse (2013), and Tejeda et al. (2001) provided evidence that the four I's correlate with transactional and laissez-faire factors, proposing that they are not unique to transformational leadership. Alatawi (2013, 2015), Northouse (2013), and Tejeda et al. (2001) affirmed that the four I's correlate highly with each other, indicating that they are not independent from each other. Recently, a study by Alatawi (2013) about transformational leadership style and its linkage to turnover intention strongly supported these criticisms and revealed a new challenge to the conceptual clarity and construct validity of the four I's. 


\section{CLAIM}

The additive effect of transformational leadership is a myth. Several studies have claimed that transformational leadership consists of II, IM, IS, and IC (Avolio, 2011; Bass \& Riggio, 2006; Dabke, 2016; Hall et al., 2015). These four I's may not have an additive influence. Furthermore, transformational leadership might not produce a total effect that is the same as the sum of the effects of II, IM, IS, and IC. The combined influence of the four I's may not represent the influence of transformational leadership. The purpose of this paper was to reexamine the additive effect of transformational leadership model in order to refine and improve the perception of the transformational leadership theory.

\section{REASON}

Based on the additive effect of the transformational leadership model, transformational leadership comprises II, IM, IS, and IC. The relevant literature proposes that, even if a manager possesses merely one component of transformational leadership, such a manager would be considered transformational. Overwhelming empirical research has claimed that transformational leadership is a highly effective style of leadership at all managerial levels and in all kinds of organizations. Supporters of the current model have highlighted that subordinates of transformational managers are more committed to their job, more engaged, and more satisfied, and thus, they produce more! The literature sustaining this model of transformational leadership and its four I's presents it as an additive model that results in performance beyond expectations, in which the extra effort results in satisfactory and unexpected outcomes (see Figure 1; Avolio, 2011; Bass \& Avolio, 1990; Bromley \& Kirschner-Bromley, 2007; Erkutlu, 2008; Hall et al., 2015; Judge \& Bono, 2000; Kivlighan \& Tarrant, 2001; Muenjohn, 2010; Muenjohn \& Armstrong, 2008; Pearce \& Sims, 2002; Pongpearchan, 2016; Smith, 2011; Vance \& Larson, 2002).

According to proponents of the examined model, the four I's (II, IM, IS, and IC) have an additive effect. Advocates of the current model have suggested that each of the four I's is essential to the process of organizational transformation. Researchers who have studied the four I's have provided adequate empirical validity to the claim that the effect of each of the variables is additive. The related literature claims that the reviewed model identifies the distinctive influence on organizational performance from each of the four variables and that the joint influence of these variables characterizes the influence of transformational leadership. Such a model focuses on the effects of possessing each of the four I's (Avolio, 2011; Bass \& Avolio, 1990; Erkutlu, 2008; Gellis, 2001; Ghasabeh, Reaiche, \& Soosay, 2015; Hall et al., 2015). 


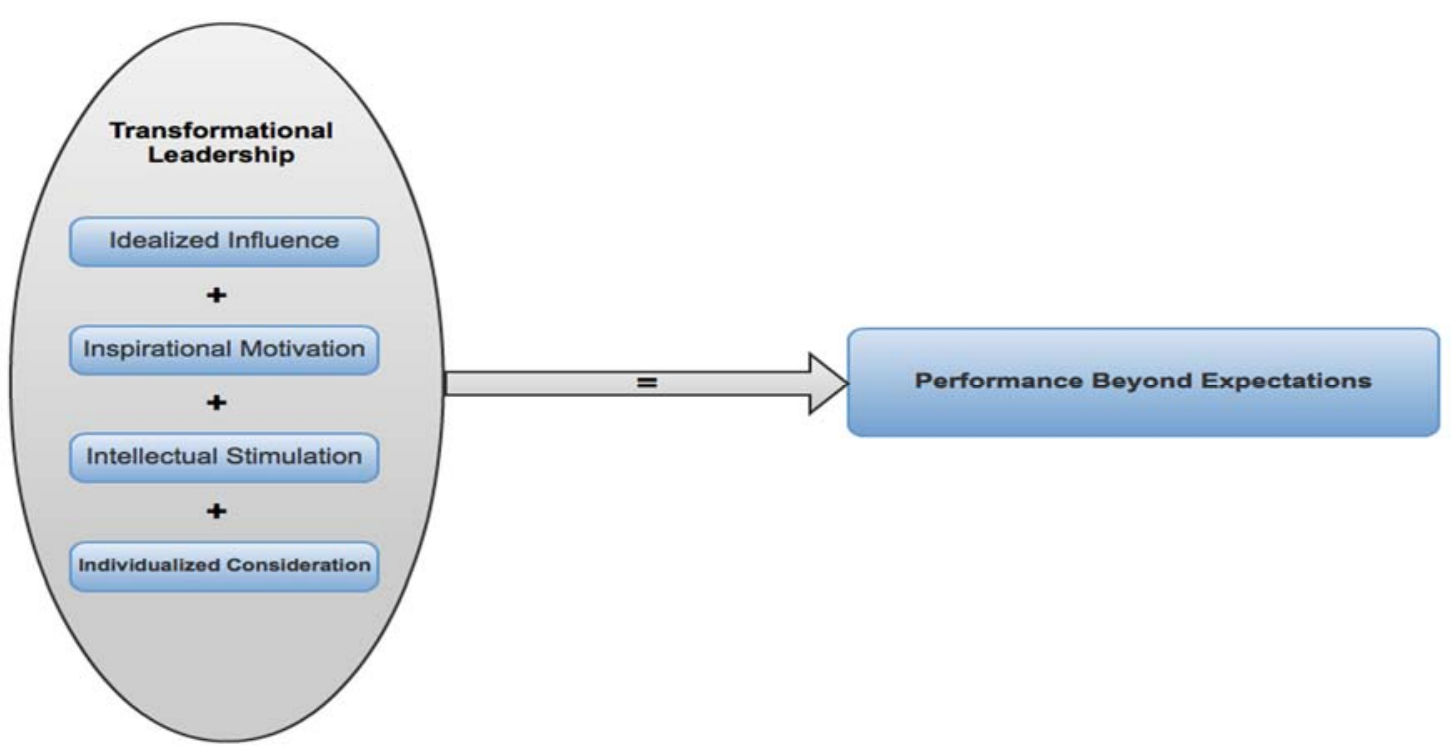

Figure 1 The Additive Effect of Transformational Leadership Model

Adapted from “The Implications of Transactional and Transformational Leadership for Individual, Team, and Organizational Development,” by B. M. Bass and B. J. Avolio, 1990, Research in Organizational Change and Development, 4(1), p. 231.

The additive effect of transformational leadership claimed by earlier research shows the powerful joint outcomes of the four I's: performance beyond expectations. This model also suggests that, in order for managers to achieve performance beyond expectations, they must combine all of the four I's together into one leadership style. Supervisors who utilize the four I's in the workplace do so by being charismatic, motivators, innovators, and people-oriented leaders, and they inspire employees to excel. The four I's transform subordinates into more productive workers motivated to go beyond their own self-interests for the good of the organization. Overwhelming research has claimed that managers who pull together the four I's of transformational leadership style generate greater impacts than managers who employ any other style of leadership by producing superior levels of performance, motivation, commitment, satisfaction, and other organizational outcomes. As managers compile and implement the four I's of transformational leadership style, the model predicts that they will attain outcomes beyond organizational expectations (Avolio, 2011; Bass \& Avolio, 1990; Bromley \& Kirschner-Bromley, 2007; Caillier, 2014; Effelsberg, Solga, \& Gurt, 2014; Erkutlu, 2008; Hall et al., 2015; Hannah, Sumanth, Lester, \& Cavarretta, 2014; Judge \& Bono, 2000; Kivlighan \& Tarrant, 2001; Muenjohn, 2010; Muenjohn \& Armstrong, 2008; Pearce \& Sims, 2002; Smith, 2011; Vance \& Larson, 2002; Vesa \& Hasu, 2015). However, a recent study contradicted the extant literature. 
In a study of 356 employees from 14 organizations in Southern California, Alatawi (2013) examined the relationship between transformational leadership style and turnover intention. Studying a variety of organizations and employees at all managerial levels helped to ameliorate the potential effects that may occur from targeting subjects from a single site. Alatawi reported that $17 \%$ of the variance in the levels of turnover intention among the employees was explained by transformational leadership style. Furthermore, 22\%, 10\%, 16\%, and 18\% of the variance in the levels of turnover intention among the employees was explained by II, IM, IS, and IC, respectively (Alatawi, 2013), translating to $66 \%$, not $17 \%$.

\section{EVIDENCE}

One main assumption of the additive effect of the transformational leadership model is that each of the four I's is thought to be independent, each producing an independent impact on turnover intention. An additive effect implies that the effect of transformational leadership on turnover intention produces a total effect that is the same as the sum of the effects of II, IM, IS, and IC on turnover intention. Based on the assumption of an additive effect of transformational leadership, it would be rationally indicated that the four I's all together must explain around $66 \%$ of the variance in levels of turnover intention $(22 \%+10 \%+16 \%+18 \%$; see Table 1$)$, according to the results of Alatawi's (2013) study. However, Alatawi provided proof that the four I's combined as transformational leadership style explained only $17 \%$ of the variance in the levels of turnover intention. As stated above, the four I's combined together (17\%) did not yield a total effect the same as the sum of the effects of II, IM, IS, and IC (22\% $+10 \%+16 \%+18 \%)$. That is to say, the combined influence of the four variables did not represent the influence of transformational leadership.

This evidence shows that the effect of each of the four I's is not additive. They are not independent, distinct, or coexisting factors that contribute distinct additive effects to transformational leadership. Thus, the four I's may not be legitimate factors of transformational leadership, conceptually explain the phenomenon of transformational leadership style, or construct transformational leadership. Thus, a manager who possesses merely one component of transformational leadership would not be considered transformational. 
Table 1 Correlations between Transformational Leadership Style and Its Four I’s With Turnover Intention

\begin{tabular}{lcccc}
\hline Variables & $\begin{array}{c}\text { Spearman's } \\
\text { rho }\end{array}$ & $R^{2}$ & $\begin{array}{c}t \text {-test value for } \\
\text { hypothesis } r=0\end{array}$ & $p$ level \\
\hline TLS \& TI & -0.41 & 0.17 & -6.40 & $<.01$ \\
\hline II \& TI & -0.47 & 0.22 & -7.60 & $<.01$ \\
\hline IM \& TI & -0.32 & 0.10 & -4.92 & $<.01$ \\
\hline IS \& TI & -0.40 & 0.16 & -6.34 & $<.01$ \\
\hline IC \& TI & -0.42 & 0.18 & -6.62 & $<.01$ \\
\hline
\end{tabular}

Note: TLS = transformational leadership style; TI = turnover intention; II = idealized influence; IM = inspirational motivation; IS = intellectual stimulation; IC = individualized consideration. Adapted from The Relationship Between Transformational Leadership Style and Managerial-Caused Turnover Intention: PIHRA Members and Their Subordinates (Doctoral dissertation), by M. A. Alatawi, 2013, pp. 106-118, available from ProQuest Dissertations and Theses database (UMI No. 3570991).

\section{DISCUSSION}

Despite the research sustaining the four I's that has claimed to add empirical validity to the additive effect of each of the variables, the current paper argues that the four I's are indistinct, do not coexist, and clearly have no additive effect. Some researchers have highlighted that the four I's overlap with each other, indicating that they are not distinctly delimited (Lee, 2014; MacKenzie et al., 2005; Northouse, 2013; Rickards \& Clark, 2006; Tracey \& Hinkin, 1998). These four factors correlate with transactional and laissez-faire factors, implying that they are not distinctive to transformational leadership style (Lee, 2014; Northouse, 2013; Tejeda et al., 2001). They correlate highly with each other, signifying also that they are not independent from each other or distinct factors (Alatawi, 2013, 2015; Northouse, 2013; Tejeda et al., 2001). This paper adds new criticism to the conceptual clarity of the four I's and to their composite construct of transformational leadership.

This paper argued that the concept of the additive effect of transformational leadership is ambiguous and provided evidence that the four I's also do not have an additive effect. It highlighted that the four I's combined together as the transformational leadership style explains $17 \%$ of the variance in the levels of turnover intention (Alatawi, 2013). However, it also indicated that the sum of the four I's explains $66 \%$ of the variance in the levels of turnover intention (Alatawi, 2013). Therefore, it concluded that the influence of transformational leadership does not generate a total outcome that is the same as the sum of the effects of II, IM, IS, and IC. In other words, the combined effect of the four I's does not characterize the influence of transformational leadership. The current paper concluded that the additive effect of transformational leadership is a myth. Therefore, researchers should not introduce the 
four I's as a valid leadership model.

The four I's may not conceptually explain the phenomenon of transformational leadership. Their ambiguity, indistinctness, and delimitation create doubts about their construct validity. Consequently, the four I's may not be legitimate factors of transformational leadership. The ambiguity in the four I's may have led to ambiguity in approaching or measuring the phenomenon of transformational leadership. This ambiguity surrounding the four I's creates doubts not only about their construct validity to transformational leadership but also about all theoretical justification and measurements that were built on their ideology. The additive effect of transformational leadership model was based on the four I's, as were most of Bass's, Avolio's, and their colleagues' work, such as the full-range leadership model and the Multifactor Leadership Questionnaire (Avolio, 2011; Bass \& Riggio, 2006; Muenjohn \& Armstrong, 2008). Theoretical research is needed with respect to most of Bass's and Avolio's claims, which were based on the four I's.

The claim that transformational leadership style results in performance beyond expectations (Bass \& Avolio, 1990) may still raise serious concerns. Taking into consideration Ohio State University's and the University of Michigan's conclusion that there is no best leadership style (Latham, 2014; Lussier \& Achua, 2012), the claim that transformational leadership is a highly effective style of leadership compared to other leadership styles in all kinds of organizations at all managerial levels (Avolio, 2011; Hall et al., 2015; Muenjohn, 2010) must be reexamined. Indeed, the statement that managers who pull together the four I's generate greater impacts than managers who employ any other style of leadership (Caillier, 2014; Effelsberg et al., 2014; Vesa \& Hasu, 2015) needs serious attention.

To conclude, it can be very advantageous for researchers to avoid presenting the four I's as a legitimate leadership model or as an approach to transformational leadership theory. The additive effect of the transformational leadership model must not be utilized in research and must be deleted from new editions of books. The four I's should not be used as a legitimate leadership style in research. A manager who possesses merely one component of transformational leadership should not be considered transformational. Future research concerning the transformational leadership theory should focus on refining and revising the work of Bass and his colleagues, especially related to transformational leadership theory: transformational, transactional, and laissez-faire leadership styles. Theory in this domain is seriously underdeveloped; thus, there is a need for a new theory that justifies these leadership styles with greater conceptual clarity. 


\section{ACKNOWLEDGMENT}

I would like to express my deepest appreciation to Dr. Casey Goodall for his valuable feedback and his contribution in stimulating suggestions and encouragement, which helped me to conduct this study.

\section{REFERENCES}

Alatawi, M. A. (2013). The relationship between transformational leadership style and managerial-caused turnover intention: PIHRA members and their subordinates (Doctoral dissertation).

Alatawi, M. A. (2015). The 21st-century managerial style. Saarbrucken, Germany: LAP Lambert Academic.

Avolio, B. J. (2011). Full range leadership development (2nd ed.). Thousand Oaks, CA: Sage.

Bass, B. M., \& Avolio, B. J. (1990). The implications of transactional and transformational leadership for individual, team, and organizational development. Research in Organizational Change and Development, 4(1), 231-272.

Bass, B. M., \& Riggio, R. E. (2006). Transformational leadership. Mahwah, NJ: Erlbaum.

Bromley, H. R., \& Kirschner-Bromley, V. A. (2007). Are you a transformational leader? Physician Executive, 33(6), 54.

Caillier, J. G. (2014). Toward a better understanding of the relationship between transformational leadership, public service motivation, mission valence, and employee performance: A preliminary study. Public Personnel Management, 43(2), 218-239. http://dx.doi.org/10.1177/0091026014528478

Dabke, D. (2016). Impact of leader's emotional intelligence and transformational behavior on perceived leadership effectiveness: A multiple source view. Business Perspectives \& Research, 4(1), 27-40.

Effelsberg, D., Solga, M., \& Gurt, J. (2014). Getting followers to transcend their selfinterest for the benefit of their company: Testing a core assumption of transformational leadership theory. Journal of Business \& Psychology, 29(1), 131-143. http://dx.doi.org/10.1007/s10869-013-9305-x

Erkutlu, H. (2008). The impact of transformational leadership on organizational and leadership effectiveness: The Turkish case. Journal of Management Development, 27(7), 708-726. http://dx.doi.org/10.1108/02621710810883616

Gellis, Z. D. (2001). Social work perceptions of transformational and transactional leadership in health care. Social Work Research, 25(1), 17-25. https://doi.org/10.1093/swr/25.1.17 
Ghasabeh, M. S., Reaiche, C., \& Soosay, C. (2015). The emerging role of transformational leadership. Journal of Developing Areas, 49(6), 459-467. https://doi.org/10.1353/jda.2015.0090

Grant, A. M. (2012). Leading with meaning: Beneficiary contact, prosocial impact, and the performance effects of transformational leadership. Academy of Management Journal, 55(2), 458-476. https://doi.org/10.5465/amj.2010.0588

Hall, J., Johnson, S., Wysocki, A., \& Kepner, K. (2015). Transformational leadership: The transformation of managers and associates. Retrieved from http://edis.ifas.ufl.edu/pdffiles/HR/HR02000.pdf

Hamstra, M., Van Yperen, N., Wisse, B., \& Sassenberg, K. (2014). Transformational and transactional leadership and followers' achievement goals. Journal of Business \& Psychology, 29(3), 413-425. https://doi.org/10.1007/s10869-0139322-9

Hannah, S. T., Sumanth, J. J., Lester, P., \& Cavarretta, F. (2014). Debunking the false dichotomy of leadership idealism and pragmatism: Critical evaluation and support of newer genre leadership theories. Journal of Organizational Behavior, 35(5), 598-621. https://doi.org/10.1002/job.1931

Judge, T. A., \& Bono, J. E. (2000). Five-factor model of personality and transformational leadership. Journal of Applied Psychology, 85(5), 751-765. http://dx.doi.org/10.1037/0021-9010.85.5.751

Kivlighan, D., Jr., \& Tarrant, J. M. (2001). Does group climate mediate the group leadership-group member outcome relationship? A test of Yalom's hypotheses about leadership priorities. Group Dynamics: Theory, Research, and Practice, 5(3), 220-234. http://dx.doi.org/10.1037/1089-2699.5.3.220

Latham, J. R. (2014). Leadership for quality and innovation: Challenges, theories, and a framework for future research. Quality Management Journal, 21(1), 11-15.

Lee, M. (2014). Transformational leadership: Is it time for a recall? International Journal of Management and Applied Research, 1(1), 17-29. https://doi.org/10.18646/2056.11.14-002

Lussier, R. N., \& Achua, C. F. (2012). Leadership: Theory, application, and skill development (5th ed.). Cincinnati, $\mathrm{OH}$ : South-Western College.

MacKenzie, S. B., Podsakoff, P. M., \& Jarvis, C. B. (2005). The problem of measurement model misspecification in behavioral and organizational research and some recommended solutions. Journal of Applied Psychology, 90(4), 710730. http://dx.doi.org/10.1037/0021-9010.90.4.710

Muenjohn, N. (2010). Transformational leadership: A new force in leadership research. In Z. Haqq (Ed.), Proceedings of the 12th International Business 
Research Conference, Melbourne, Australia. Retrieved from http://www.wbiconpro.com/436-Nuttawuth.pdf

Muenjohn, N., \& Armstrong, A. (2008). Evaluating the structural validity of the Multifactor Leadership Questionnaire (MLQ), capturing the leadership factors of transformational-transactional leadership. Contemporary Management Research, 4(1), 3-14. http://dx.doi.org/10.7903/cmr.704

Northouse, P. G. (2013). Leadership theory and practice (6th ed.). Thousand Oaks, CA: Sage.

Pearce, C. L., \& Sims, H. R. (2002). Vertical versus shared leadership as predictors of the effectiveness of change management teams: An examination of aversive, directive, transactional, transformational, and empowering leader behaviors. Group Dynamics: Theory, Research, and Practice, 6(2), 172-197. http://dx.doi.org/10.1037/1089-2699.6.2.172

Pongpearchan, P. (2016). Effect of transformational leadership on strategic human resource management and firm success of Toyota's dealer in Thailand. Journal of Business \& Retail Management Research, 10(2), 53-63.

Rickards, T., \& Clark, M. (2006). Dilemmas of leadership. Abingdon, United Kingdom: Taylor \& Francis.

Smith, M. A. (2011). Are you a transformational leader? Nursing Management, 42(9), 44-50. http://dx.doi.org/10.1097/01.NUMA.0000403279.04379.6a

Tejeda, M. J., Scandura, T. A., \& Pillai, R. (2001). The MLQ revisited: Psychometric properties and recommendations. Leadership Quarterly, 12(1), 31-52. http://doi.org/10.1016/S1048-9843(01)00063-7

Tracey, J., \& Hinkin, T. (1998). Transformational leadership or effective managerial practices? Group \& Organization Management, 23(3), 220-236. http://dx.doi.org/10.1177/1059601198233002

Vance, C., \& Larson, E. (2002). Leadership research in business and health care. Journal of Nursing Scholarship, 34(2), 165-171. http://dx.doi.org/10.1111/j.1547-5069.2002.00165.x

Van Knippenberg, D., \& Sitkin, S. B. (2013). A critical assessment of charismatictransformational leadership research: Back to the drawing board? Academy of Management Annals, 7(1), 1-60. http://dx.doi.org/10.1080/19416520.2013.759433

Vesa, P., \& Hasu, M. (2015). Moderating effects of transformational leadership between external team learning and research team performance outcomes. $R \& D$ Management, 45(3), 304-316. http://dx.doi.org/10.1111/radm.12091 
Weathington, B. L., Cunningham, C. J., \& Pittenger, D. J. (2010). Research methods for the behavioral and social sciences. Hoboken, NJ: Wiley.

Zhu, Y., \& Akhtar, S. (2014). How transformational leadership influences follower helping behavior: The role of trust and prosocial motivation. Journal of Organizational Behavior, 35(3), 373-392. http://dx.doi.org/10.1002/job.1884 
